\title{
Central B-Cell Tolerance: Where Selection Begins
}

\author{
Roberta Pelanda and Raul M. Torres \\ Integrated Department of Immunology, National Jewish Health and University of Colorado Denver \\ School of Medicine, Denver, Colorado 80206 \\ Correspondence: pelandar@njhealth.org
}

The development of an adaptive immune system based on the random generation of antigen receptors requires a stringent selection process that sifts through receptor specificities to remove those reacting with self-antigens. In the B-cell lineage, this selection process is first applied to $\lg \mathrm{M}^{+}$immature B cells. By using increasingly sophisticated mouse models, investigators have identified the central tolerance mechanisms that negatively select autoreactive immature $B$ cells and prevent inclusion of their antigen receptors into the peripheral B-cell pool. Additional studies have uncovered mechanisms that promote the differentiation of nonautoreactive immature B cells and their positive selection into the peripheral B-cell population. These mechanisms of central selection are fundamental to the generation of a naïve B-cell repertoire that is largely devoid of self-reactivity while capable of reacting with any foreign insult.

B cell generation in the bone marrow of adult mammals occurs through a tightly controlled developmental process (Fig. 1). Productive rearrangement of immunoglobulin heavy $(\mathrm{IgH})$ and light $(\mathrm{IgL})$ chain gene segments in $\mathrm{B}$ lymphocyte precursor cells, in addition to the expression of Ig- $\alpha$ (CD79a) and Ig- $\beta$ (CD79b), result in the generation and expression on the cell surface of a mature B-cell antigen receptor (BCR). Whereas the combination of $\mathrm{Ig} \mathrm{H}$ and L chains determines the antigenic specificity of the newly formed BCR, their association with Ig- $\alpha$ and Ig- $\beta$ allows transduction of a signal inside the cell that directs cell fate. Developing B cells first express a mature BCR on the cell surface in the form of IgM and as such are classified as immature B cells (Fig. 1) (Hardy et al. 1991; Pelanda et al. 1996). It is at the immature B-cell stage that the BCR is tested for the first time for reactivity against autoantigens. This test determines whether the immature B cell and the antibody it expresses on the surface will be selected into the peripheral B-cell repertoire. Central B-cell tolerance, in fact, refers to the process that negatively selects newly generated immature $B$ cells that react with a self-antigen in the bone marrow environment. This is considered the first checkpoint of B-cell tolerance, and the results of this checkpoint are fundamental to the generation of a naive repertoire that contains foreign reactive antibodies and is largely devoid of selfreactive specificities.

On passing this central checkpoint, immature $\mathrm{B}$ cells continue to differentiate into transitional and mature B cells before and after they travel to the spleen (Loder et al. 1999; Allman

Editors: Diane Mathis and Alexander Y. Rudensky

Additional Perspectives on Immune Tolerance available at www.cshperspectives.org

Copyright (C) 2012 Cold Spring Harbor Laboratory Press; all rights reserved; doi: 10.1101/cshperspect.a007146

Cite this article as Cold Spring Harb Perspect Biol 2012;4:a007146 
R. Pelanda and R.M. Torres

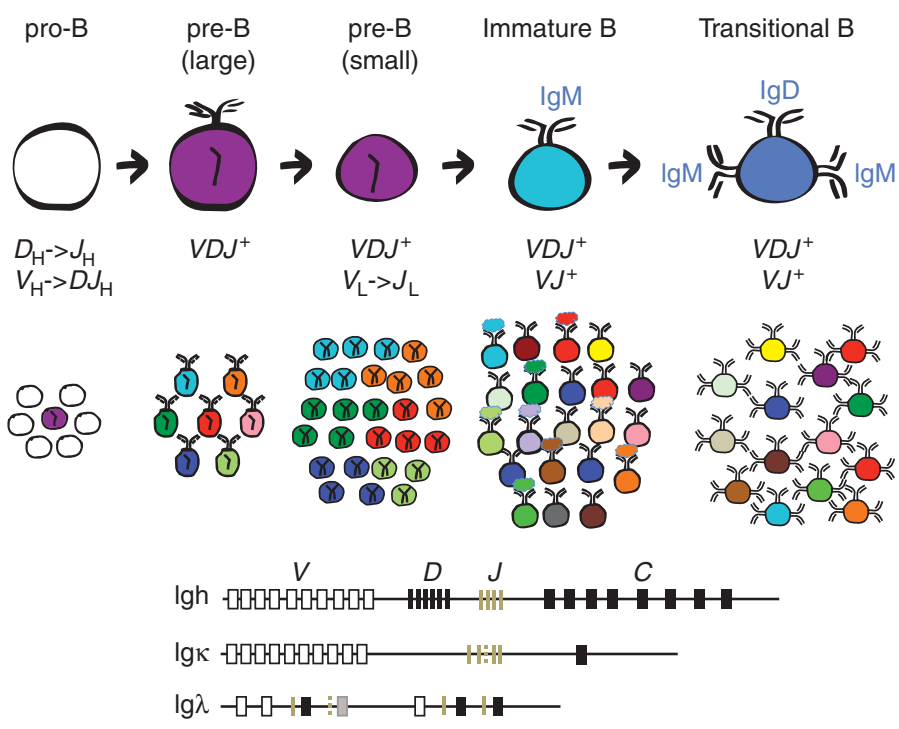

Figure 1. Schematic representation of B-cell development and Ig loci in mice. Large pro-B cells initiate Ig gene rearrangement at the IgH locus. Expression of a $\mathrm{H}$ chain following a productive $V_{\mathrm{H}} D_{\mathrm{H}} J_{\mathrm{H}}$ recombination event promotes the differentiation of large pre- $\mathrm{B}$ cells in which the expression of pre-BCR $(\mathrm{H}$ chain pairing with surrogate light chains) results in the clonal expansion of $\mathrm{H}$ chain-positive pre- $\mathrm{B}$ cells and the development of small pre-B cells. Expression of conventional L chains following productive rearrangements at the IgL chain loci in small pre-B cells promotes the development of a diverse population of $\operatorname{IgM}^{+}$immature B cells, which then differentiate into $\operatorname{IgM}^{+} \mathrm{IgD}^{+}$transitional B cells. The scheme of mouse Ig $\mathrm{H}$, $\kappa$, and $\lambda$ loci (not to scale) indicate the presence of $V$ (white rectangles), $D$ (black vertical lines), $J$ (brown vertical lines; a dashed line indicates a nonfunctional element), and $C$ (black rectangles; a gray rectangle indicates a nonfunctional element) gene segments. The scheme does not represent the number of $V_{\mathrm{H}}, D_{\mathrm{H}}$, and $V \kappa$ gene segments in the actual Ig loci.

et al. 2001; Su and Rawlings 2002; Tarlinton et al. 2003). Analysis of the bone marrow early immature B-cell repertoire indicates that a staggering $50 \%-75 \%$ of these cells express BCRs that are specific for self-antigens, both in mice and humans (Grandien et al. 1994; Wardemann et al. 2003). Similar studies performed on cell populations at the other end of this central checkpoint, namely, transitional and naïve mature $B$ cells in spleen and blood, show a much lower frequency (20\%-40\%) of cells expressing autoreactive antibodies (Grandien et al. 1994; Wardemann et al. 2003), demonstrating the stringency and limitation of this initial selection step. Moreover, individuals affected by autoimmune disease such as lupus erythematosus or rheumatoid arthritis bear many more autoreactive cells in their new emigrant and naïve B-cell populations (Samuels et al. 2005; Yurasov et al. 2005), indicating a defect in central (and/or peripheral) B-cell selection. Thus, it seems important that the development of autoreactive immature B cells be constrained to prevent the potential occurrence of autoimmunity. However, there are also reasons to believe that the high frequency of autoreactive specificities generated during primary Ig gene rearrangements may be necessary for the generation of the peripheral B-cell repertoire (Pelanda et al. 1997; Kohler et al. 2008). Indeed, a fraction of autoreactive immature B cells, those manifesting a low level of self-reactivity, do bypass the central checkpoint of tolerance and differentiate into mature B cells (Hayakawa et al. 2003; Wardemann et al. 2003; Wen et al. 2005). The inclusion of these weakly self-reactive B cells in the peripheral B-cell repertoire may allow recognition of a broader spectrum of foreign molecules, potentially decreasing the negative impact of infec- 
tions, especially at early stages (Mouquet et al. 2010).

What are the rules that govern the selection of immature B cells? Most studies of central tolerance have been conducted by following the selection of B cells expressing BCRs displaying well-defined reactivity for natural or synthetic self-antigens. This has been accomplished through the use of Ig transgenic mice in which developing $\mathrm{B}$ cells have been altered to carry prerearranged $\mathrm{Ig} \mathrm{H}$ and $\mathrm{L}$ chain genes encoding antibodies of defined antigen specificity and reactivity. Here we review some of these studies, what we have learned from them, and open questions that still await answers.

\section{CLONAL DELETION IN CENTRAL B-CELL TOLERANCE: A DEFAULT MECHANISM}

The clonal selection theory proposed by Burnet at the end of the 1950s suggested that clones of lymphocytes reactive with self-antigens are eliminated to prevent immune responses against self (Burnet 1959). A variety of experiments were conducted thereafter to test this theory. Throughout the 1970s and 1980s, studies were performed injecting antibodies reactive toward Ig chains into newborn mice and rabbits with the purpose of testing whether newly generated B cells reacting with a "self-antigen," here mimicked by an anti-Ig antibody, would be deleted or modulated. Indeed, injection of anti-IgM, anti$\mathrm{IgD}$, and even anti-idiotypic antibodies in newborn animals resulted in the apparent elimination of $\operatorname{IgM}, \operatorname{IgD}$, and idiotype-expressing $\mathrm{B}$ cells, respectively (e.g., Lawton et al. 1972; Manning and Jutila 1972; Gordon et al. 1975; Tokuhisa et al. 1981; Finkelman et al. 1983; Takemori and Rajewsky 1984; Cerny et al. 1986; Gause et al. 1987). In the 1980s transgenic mice became an experimental option and some of the first Ig transgenic mice, anti-hen egg lysozyme (HEL), and anti-H-2K $\mathrm{K}^{\mathrm{k}, \mathrm{b}}$, were developed with the purpose of testing whether newly generated autoreactive B cells were either eliminated or suppressed on recognition of their specific selfantigen. These studies indicated that when an immature B cell reacts with a self-antigen with high avidity, such as a highly expressed mem- brane-bound protein, it arrests in differentiation and undergoes apoptosis within 2-3 d (Nemazee and Burki 1989; Hartley et al. 1991, 1993). In contrast, low avidity interactions with self-antigens permit further differentiation, but also cause a shortened lifespan resulting in cell deletion in the periphery (Goodnow et al. 1988). From these early in vivo studies with anti-Ig treatment and conventional Ig transgenic mice, it was concluded that clonal deletion was a major mechanism mediating central tolerance of developing autoreactive B cells, guaranteeing the elimination of autoreactive clones, and preventing immune responses against self. However, later studies showed that clonal deletion is not the primary mode of autoreactive immature Bcell selection, but rather a default mechanism that operates when another system, namely, receptor editing, fails.

\section{RECEPTOR EDITING AS A MECHANISM OF CENTRAL B-CELL TOLERANCE}

In 1993, three papers were published in The Journal of Experimental Medicine by the groups of David Nemazee (then at the National Jewish Center for Immunology and Respiratory Medicine in Denver) and Martin Weigert (then at the Fox Chase Cancer Center in Philadelphia) proposing what was then considered a radical mode of action by which the immune system could dispose of antibodies reacting with high avidity self-antigens while preserving the cells that originally produce these specificities (Gay et al. 1993; Radic et al. 1993; Tiegs et al. 1993). In their Ig transgenic mouse models in which the self-antigens were either MHC class $\mathrm{I} \mathrm{K}^{\mathrm{b}}$ or DNA, autoreactive immature B cells were shown to "edit" their antigen receptors away from autoreactivity. Specifically, autoreactive immature $\mathrm{B}$ cells were shown to reactivate their Ig gene rearrangement program at the Ig L chain loci resulting in the expression of a new $\mathrm{L}$ chain that paired with the existing $\mathrm{H}$ chain to form a nonautoreactive BCR, an event that promoted the selection of these edited B cells into the periphery (Fig. 2A). The concept of "receptor editing" was then born. However, like many other new ideas, it took some years before receptor editing 
R. Pelanda and R.M. Torres

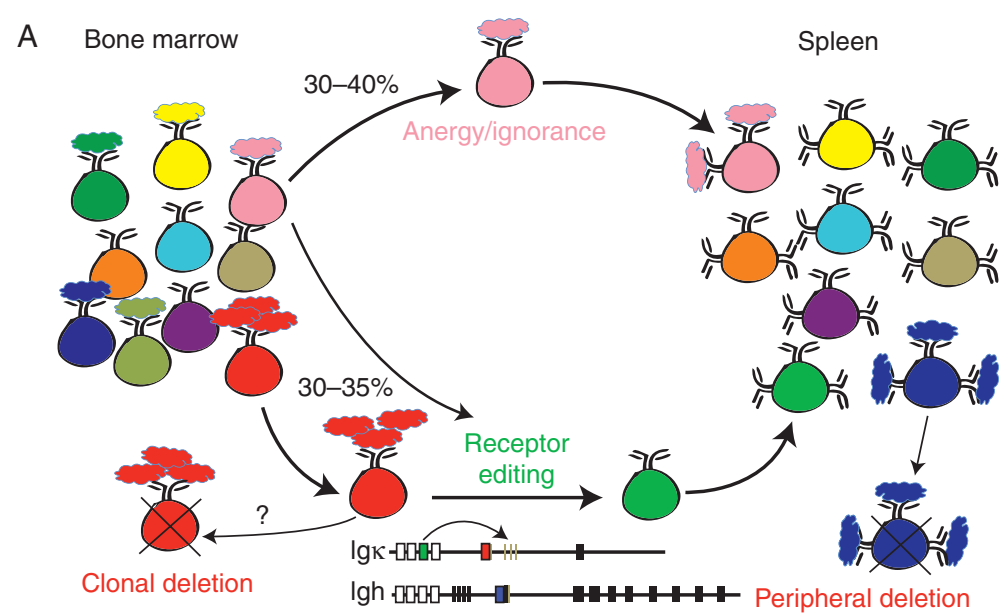

B
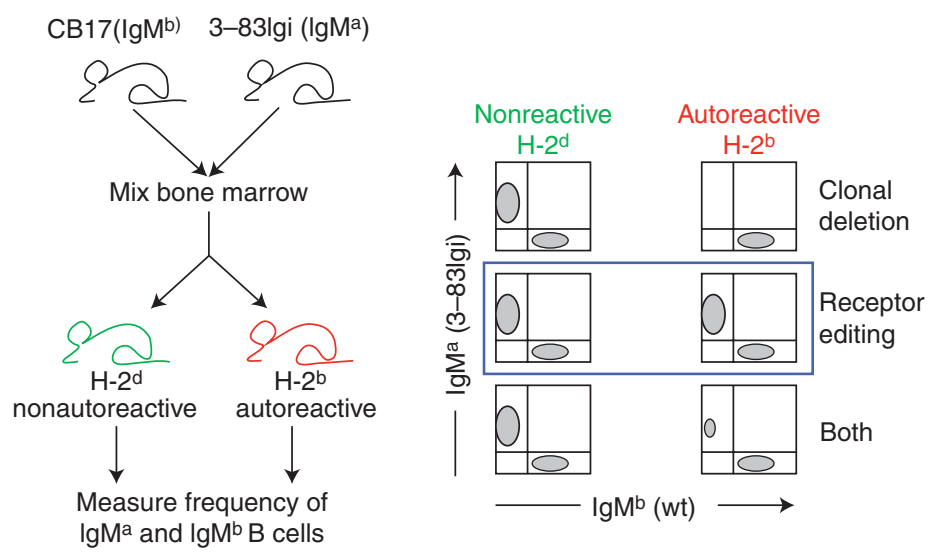

Figure 2. Receptor editing in central B-cell selection. (A) Schematic representation of central B-cell tolerance. Immature B cells reacting with low to high avidity self-antigens undergo receptor editing, here represented by a secondary rearrangement at the Igк allele. Immature B cells reacting with low avidity self-antigens can alternatively further differentiate and migrate into the spleen as anergic or ignorant B cells. Clonal deletion that occurs at a frequency that is presently unknown, but that is likely very low, is represented as a by-product of cells undergoing failed receptor editing. B cells encountering self-antigen in the periphery are represented undergoing peripheral deletion. $(B)$ Experimental setup that tested the relative contribution of receptor editing and clonal deletion to central tolerance of developing 3-83 $\mathrm{Ig}^{+} \mathrm{B}$ cells (Halverson et al. 2004). Bone marrow cells from wild-type $\operatorname{IgM}^{\mathrm{b}}$ congenic and 3-83Igi IgM $\mathrm{M}^{\mathrm{a}}$ congenic mice were mixed at equal proportion and injected into lethally irradiated recipient mice of $\mathrm{H}-2^{\mathrm{d}}$ and $\mathrm{H}-2^{\mathrm{b}}$ genetic backgrounds. The frequency of $\operatorname{IgM}^{\mathrm{a}}$ and $\operatorname{IgM}^{\mathrm{b}} \mathrm{B}$ cells in the total B-cell population was measured in mixed bone marrow chimeras of the two experimental groups. The scheme on the right represents the expected outcomes of this analysis if all anti- $\mathrm{K}^{\mathrm{b}} 3-83 \mathrm{Ig}^{+} \mathrm{B}$ cells had undergone clonal deletion (top panel), receptor editing (middle panel), or a combination of either tolerance mechanism (bottom panel) in mice expressing the self-antigen $\left(\mathrm{H}-2^{\mathrm{b}}\right)$, and relative to nonautoreactive mice $\left(\mathrm{H}-2^{\mathrm{d}}\right)$. The blue rectangle indicates the experimental findings.

would be commonly accepted as a main mechanism of central B-cell tolerance rather than a transgenic artifact.

The generation of Ig knockin mice, which bear the rearranged $V(D) J$ sequences at their physiological loci (at sites where naturally rearranged $V[D] J$ sequences are found), unequivocally showed that receptor editing is a prominent mechanism of central tolerance (Fig. 2A), occurring in all developing high avidity auto- 
reactive immature $\mathrm{B}$ cells and capable of generating a nonautoreactive B-cell population of normal size (Pelanda et al. 1997; Hippen et al. 2005; Huang et al. 2006). We now appreciate that depending on the avidity of the BCR for its own specific self-antigen, editing B cells can completely down-modulate surface expression of IgM, thus resembling pre-B cells (Pelanda et al. 1997; Hippen et al. 2005), or express low to relatively normal levels of sIgM (Gay et al. 1993; Hippen et al. 2005; Huang et al. 2006). In addition to secondary rearrangements at the $\mathrm{L}$ chain loci, receptor editing can also take place at the Ig $\mathrm{H}$ chain alleles, in the form of $\mathrm{H}$ chain replacement (Chen et al. 1995a). However, the Igk locus of mice is particularly suited for this process because of the following reasons: (1) the variable regions of $\mathrm{L}$ chains do not include $D$ elements as found in the $\mathrm{H}$ chain (Fig. 1) and thus permit a secondary recombination event between an upstream $V \kappa$ and a downstream $J \kappa$ element; (2) there are $95 V \kappa$ and four $J \kappa$ functional gene elements (Zachau 2000; Martinez-Jean et al. 2001; Brekke and Garrard 2004) allowing multiple secondary recombination events on the same allele; (3) most primary $V \kappa-J \kappa$ rearrangement events occur on $J \kappa_{1}$ and $J \kappa_{2}$ (Yamagami et al. 1999), leaving $J \kappa_{4}$ and $J \kappa_{5}$ downstream, and $V \kappa$ gene segments upstream of a $V \kappa-J \kappa$ rearrangement (in addition to the second Igк allele) as substrates of secondary recombination events; (4) recombination of the Ig $\lambda$ locus follows that of Igк (Persiani et al. 1987; Muller and Reth 1988; Arakawa et al. 1996; van der Burg et al. 2001) and can provide additional L chains in cases of persistent autoreactivity with $\kappa$ chains; and (5) recombining sequence (RS) recombination elements located $3^{\prime}$ of the Igк enhancers can recombine with upstream recombination signals to inactivate the Igк allele by deletion or inversion of the $C \kappa$ and Igк intron enhancer intervening sequences (Moore et al. 1985; Shimizu et al. 1991) removing expression of an autoreactive $\kappa$ chain in $\lambda$-expressing cells (Pelanda et al. 1997).

In contrast to the relative ease by which Igk alleles undergo secondary recombination events, the IgH locus possesses several features that limit its use as a substrate for editing. Specifically, the generation of the variable region of an $\mathrm{Ig} \mathrm{H}$ chain requires the rearrangement of a $D$ element to a $J$ element followed by that of a $V$ to a rearranged $D J$ gene segment, and this is based on the $12 / 23$ rule of the $V(D) J$ recombination process (Sakano et al. 1981). Because of this configuration, the rearrangement of a VDJ gene segment results in the deletion of all remaining $D$ elements, thus preventing a secondary canonical rearrangement event on the same allele. Although the second allele can be rearranged instead (Liu et al. 2008), this could cause the generation of B cells coexpressing two $\mathrm{H}$ chains, a rare event in wild-type mice (Barreto and Cumano 2000). In fact, it has been shown that editing at the $\mathrm{H}$ chain occurs via replacement of the $\mathrm{VH}$ element with a new $\mathrm{VH}$ gene segment by recombination of an upstream $V H$ gene either into a RS-like sequence that is located in the $3^{\prime}$ region of most $V H$ genes (Fanning et al. 1998; Zhang et al. 2003) or directly into a $\mathrm{JH}$ element (Koralov et al. 2006) in violation of the $12 / 23$ rule. $V H$ replacement, however, has a low probability of generating a productive and functional $\mathrm{H}$ chain (Koralov et al. 2006) and would not be favored because the IgH locus has already acquired a low accessible state by the time an immature B-cell tests its BCR (Inlay et al. 2006; Hewitt et al. 2008). Receptor editing at the $\operatorname{Ig} \lambda$ locus is also not favored in mice, because the locus has only three $V \lambda$ gene segments that are located in two independent rearrangement clusters with their own constant regions (Fig. 1) (Carson and Wu 1989). Thus, once an immature $B$ cell expresses an autoreactive $\lambda$ chain, alternative modes of tolerance must be used to deal with this persistent self-reactivity, and these include the rearrangement of an additional $\lambda$ chain that may dilute the expression of autoreactive BCRs (Doyle et al. 2006).

\section{RELEVANCE OF RECEPTOR EDITING IN CENTRAL B-CELL TOLERANCE}

After receptor editing was found to occur frequently in autoreactive Ig knockin mice, the relevance of this mechanism was not initially clear relative to clonal deletion and within a polyclonal B-cell population. In particular, it was difficult to envision why a mechanism would 
exist to salvage an autoreactive B cell when the immune system had already provided many examples of waste (i.e., cell death) in developing a vast repertoire. To address this issue, bone marrow chimeras were generated that harbored a mix of autoreactive knockin B cells (3-83Igi in this system) and congenic wild-type B cells, and the frequency of peripheral B cells derived from the autoreactive B-cell precursors was then contrasted to that derived from the wildtype reference population (Fig. 2B) (Halverson et al. 2004). Results were then compared to similar mixed bone marrow chimeras in which the Ig knockin B cells developed in the absence of self-antigen (Fig. 2B) (Halverson et al. 2004). These studies showed that the frequency of knockin-derived B cells was the same in the presence or absence of self-antigen and indicated that all developing autoreactive B cells undergo receptor editing without cell loss and even when comprising only $10 \%$ of the developing B-cell population. Thus, it was concluded that receptor editing is a very efficient process that can, theoretically, provide a new nonautoreactive Ig L chain to any autoreactive immature B cell. These studies resulted in three additional important conclusions: (1) the Igк locus is essential for establishing a successful and efficient receptor editing process, as shown by the fact that removal of downstream J $\mathrm{\kappa}$ substrates halves the capacity of receptor editing to procure a nonautoreactive specificity (Halverson et al. 2004); (2) nonproductive receptor editing defaults to clonal deletion as shown by the fact that partial or complete inhibition of receptor editing results in reduced or absent B-cell output (Halverson et al. 2004), respectively, consistent with previous observations in conventional Ig transgenic mice (Spanopoulou et al. 1994; Chen et al. 1995b; Xu et al. 1998); and 3) autoreactive immature B cells from conventional Ig transgenic mice most often default to clonal deletion because Ig gene recombination events at their endogenous Ig loci do not lead to inactivation of the Ig transgenes bearing the autoreactive specificity. Thus, the frequency of clonal deletion is artificially amplified (experimentally and conceptually) in the developing B-cell population of conventional Ig transgenic mice.
Additional studies have investigated whether receptor editing operates in polyclonal B-cell populations. The analysis of receptor editing in 3H9 and derivative $\mathrm{IgH}$ chain transgenic mice bearing a polyclonal Ig L chain repertoire indicated that receptor editing is operative whenever a developing $\mathrm{B}$ cell rearranges an endogenous $\mathrm{L}$ chain that pairs with the $\mathrm{H}$ chain to form an anti-DNA specificity (Chen et al. 1995b). Another study investigating the frequency of receptor editing in developing B cells bearing a prerearranged knockin Ig L chain (three different Igк chains were tested) with the endogenous Ig $\mathrm{H}$ chain repertoire indicated that $\sim 25 \%$ of immature B cells had sufficient self-reactivity to induce receptor editing (Casellas et al. 2001). This frequency may be very close to the actual occurrence of receptor editing at the Ig $\mathrm{L}$ chain loci in a wild-type B-cell population. Because $\mathrm{VH}$ replacements have been estimated to occur in $5 \%-10 \%$ of developing B cells (Zhang et al. 2003; Koralov et al. 2006), this brings the overall estimated frequency of receptor editing in a polyclonal wild-type B-cell population to $30 \%-$ $35 \%$. Finally, an elegant study by Nemazee and colleagues showed that wild-type immature B cells are capable of undergoing receptor editing on engagement of a self-antigen. In this study, a synthetic membrane antigen ( $\kappa$-macroself-Ag) was engineered to react with all $\kappa^{+} \mathrm{B}$ cells with high avidity, demonstrating the efficient induction of receptor editing in wild-type $\kappa^{+}$immature B cells with minimal or undetectable levels of clonal deletion (Ait-Azzouzene et al. 2005).

Overall, the findings of these studies suggest that $\sim 30 \%-35 \%$ of newly generated B cells in wild-type mice interact with self-antigens that deliver a signal sufficient for the induction of receptor editing. Furthermore, receptor editing is extremely efficient at providing an autoreactive B cell with a new Ig L chain (or less frequently a $\mathrm{H}$ chain) encoding a nonautoreactive specificity, and clonal deletion is a default mechanism that ensures the elimination of autoreactive immature B cells that fail receptor editing (Fig. 2A). Clonal deletion may occur when the $\mathrm{H}$ chain contributes considerably to self-reactivity, when the B cell has exhausted rearrangement options at the $\kappa$ loci, or when the B cell remains 
autoreactive after a productive $\operatorname{Ig} \lambda$ chain rearrangement. The actual extent of clonal deletion in developing $\mathrm{B}$ cells is presently unclear and may be insignificant based on the following reasoning. Repertoire studies have indicated that $\sim 50 \%-70 \%$ of immature B cells in mice react with self-antigens (Grandien et al. 1994), which is compatible with estimates in humans (Wardemann et al. 2003). Given that 30\%-35\% of the immature B cells undergo receptor editing, the remaining autoreactive immature B cells (15\%-35\%) must undergo a different selection process, which is clonal deletion, anergy, or ignorance. Because $30 \%-40 \%$ of transitional B cells remain autoreactive after selection in the bone marrow (Grandien et al. 1994; Wardemann et al. 2003), this suggests that those autoreactive immature B cells that do not undergo editing are selected via ignorance or anergy to selfantigen, and very few undergo clonal deletion (Fig. 2A).

\section{CENTRAL B-CELL TOLERANCE FOR LOW AVIDITY INTERACTIONS}

Early studies based on conventional transgenic mice also indicated that low avidity interactions between immature B cells and self-antigens result in the development of anergic peripheral B cells (Goodnow et al. 1988; Benschop et al. 2001). Given that the extent of clonal deletion was overrepresented by the use of conventional Ig transgenic mouse models, it was important to revisit central B-cell tolerance toward low avidity self-antigens in a more physiological context. This question was addressed by studying the fate of $\mathrm{H}$ chain transgenic $+\mathrm{L}$ chain knockin anti-HEL B cells developing in the presence of soluble HEL (Hippen et al. 2005). In this model, only half of the low avidity autoreactive B cells developed anergy, whereas the other half underwent receptor editing (Hippen et al. 2005), in contrast to conventional Ig H and L chain transgenic mice in which most B cells were anergic (Goodnow et al. 1988). A similar dichotomy in tolerance induction has been observed in wild-type B cells that develop in the presence of low concentrations of a $\mathrm{\kappa}$-macroself-Ag (Ait-Azzouzene et al. 2006). Together these findings suggest that some of the editing $\mathrm{B}$ cells in the wild-type repertoire may be low avidity autoreactive immature B cells (Fig. 2A). The reasons for why some low avidity autoreactive immature $\mathrm{B}$ cells undergo receptor editing whereas others develop anergy are still unresolved, but may relate to cell competition for self-Ag in selective marrow microenvironments.

\section{POTENTIAL HAZARDS OF RECEPTOR EDITING}

The initial proposal of receptor editing as a mechanism of tolerance was controversial also because it implied that autoreactive B cells would survive while editing occurred, with the subsequent risk that these cells may be selected into the peripheral B-cell compartment. In fact, further studies in mouse models in which autoreactive B cells undergo extensive receptor editing indicates that this process can generate intermediary cell types that coexpress autoreactive and nonautoreactive BCRs (Fig. 3). Under circumstances that are yet to be established, some of these haplotype-included B cells are able to proceed in differentiation and are selected into the peripheral and mature B-cell populations (Li et al. 2002; Liu et al. 2005; Huang et al. 2006). The frequency of peripheral haplotypeincluded autoreactive B cells in these mouse models varies from $15 \%$ to $30 \%$ of the peripheral B-cell pool. Assuming that this frequency reflects the probability of generating haplotypeincluded B cells from receptor editing, and that $30 \%-35 \%$ of wild-type B cells are generated via receptor editing (Fig. 2A), we would expect $4 \%-10 \%$ of wild-type peripheral B cells to be haplotype-included and potentially still autoreactive. In fact, $\sim 3 \%-10 \%$ of $\mathrm{B}$ cells in wildtype mice have been shown to coexpress two Ig L (or more rarely two $\mathrm{H}$ ) chains (Giachino et al. 1995; Barreto and Cumano 2000; Rezanka et al. 2005; Casellas et al. 2007; Velez et al. 2007), and data exist that suggest that these cells more frequently react with self-antigens relative to single antibody-expressing B cells (Casellas et al. 2007). Precisely how many of these haplotypeincluded B cells are self-reactive, whether they are potential mediators of autoimmunity, and 
R. Pelanda and R.M. Torres
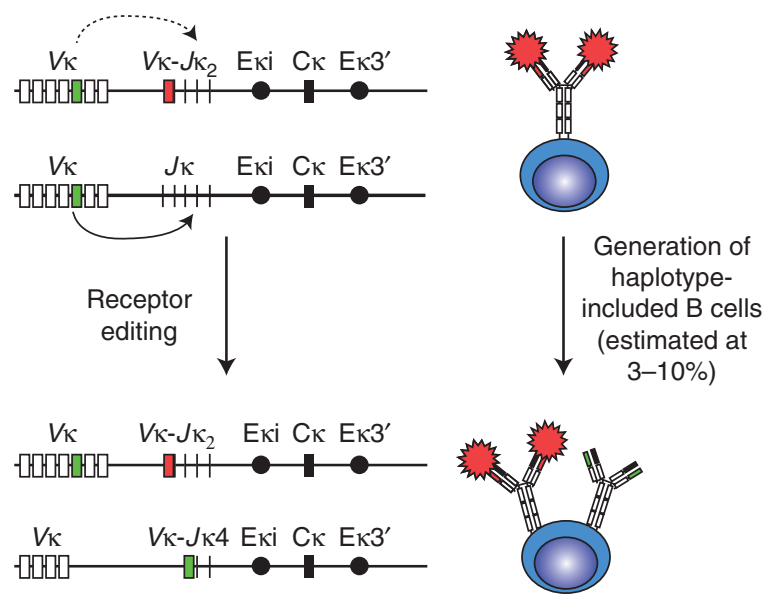

Figure 3. Receptor editing generates a small population of haplotype-included B cells. During receptor editing, a potential rearrangement at the second Igא allele (intact arrow), or at the $\operatorname{IgH}$ or Ig $\lambda$ alleles, results in the generation of cells coexpressing two or more types of $\mathrm{H}$ and $\mathrm{L}$ chains. Some of these haplotype-included B cells are selected into the peripheral B-cell population expressing both autoreactive and nonautoreactive antibodies. Note that if receptor editing occurs on the original rearranged Igк allele (dotted arrow), the previously used $V-J$ sequence would be deleted.

what are the self-antigens they recognize, are questions still awaiting clear answers.

Finally, the evolutionary purpose of receptor editing remains obscure, especially given its associated risk of promoting the development of autoreactive B cells. However, it can be argued that receptor editing may be important for rescuing those pre-B cells that have undergone a productive IgH chain rearrangement event and, thus, to promote repertoire diversification (Pelanda et al. 1997; Kohler et al. 2008).

\section{POSITIVE SELECTION OF IMMATURE B CELLS: AN ACTIVE PROCESS}

Immature B cells that display nonautoreactive BCRs continue to differentiate and progressively acquire expression of surface markers typical of more mature B cells, such as IgD, CD21, and $\mathrm{CD} 23$, before and after they travel to the spleen (Loder et al. 1999; Allman et al. 2001; Su and Rawlings 2002; Tarlinton et al. 2003). The surface expression of a mature BCR is an absolute requirement for this differentiation event, because genetically altered pre- $\mathrm{B}$ cells unable to express mature BCRs do not differentiate or leave the bone marrow (Reichman-Fried et al.
1990; Spanopoulou et al. 1994; Young et al. 1994). Moreover, targeting the Ig- $\alpha /$ Ig- $\beta$ heterodimer to the cell membrane promotes B-cell development in the absence of $\operatorname{Ig} \mathrm{H}$ and $\mathrm{L}$ chains (Bannish et al. 2001), suggesting that cell surface assembled BCRs transduce signals that promote differentiation of immature B cells in the absence of antigen binding. This antigenindependent $\mathrm{BCR}$ signal is referred to as a tonic or basal signaling.

Further studies investigating the nature and function of tonic BCR signaling in immature B cells have found that the ongoing differentiation of nonautoreactive immature $\mathrm{B}$ cells is dependent on a certain threshold of tonic BCR signaling (Heltemes and Manser 2002; Wang et al. 2004; Rowland et al. 2010a). Specifically, expression of BCRs on the cell surface of immature B cells must reach a certain level such that their concerted tonic signal achieves the threshold required for initiating cell differentiation into the transitional stage (Fig. 4) (Rowland et al. 2010a). Even a 30\% reduction of wild-type BCR level has a negative impact on the differentiation of immature into transitional and mature B cells, and this impact is more severe with still lower BCR expression (Rowland et al. 2010a). We have 


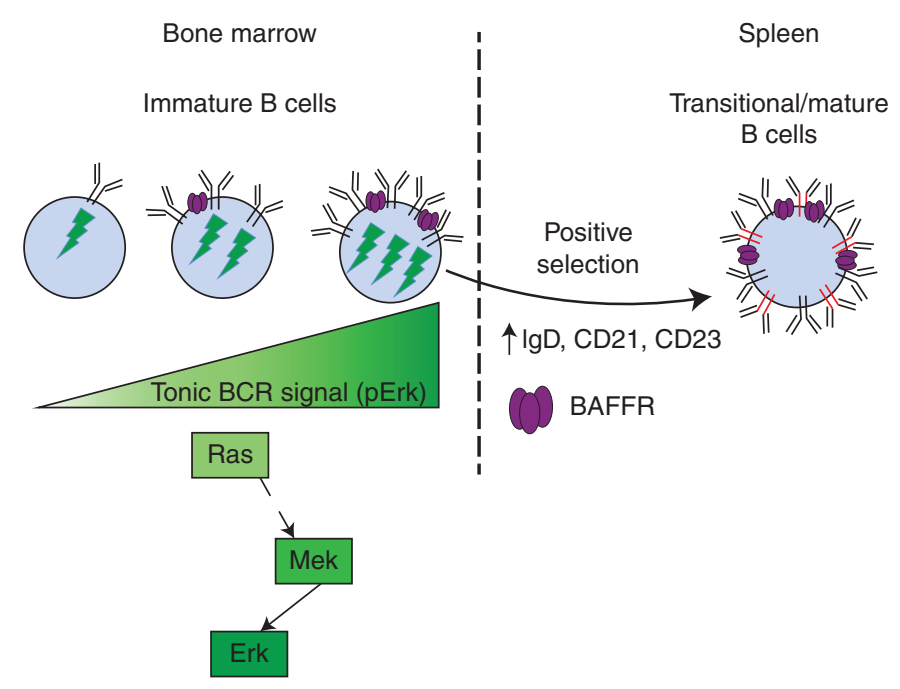

Figure 4. Positive selection of nonautoreactive immature B cells into the peripheral B-cell compartment requires a threshold level of tonic BCR signaling. Differentiation of nonautoreactive immature B cells into transitional and mature B cells and entry into the peripheral B-cell population depends on a certain threshold of BCR expression and tonic BCR signaling, which is translated by the Ras-Mek-Erk signaling pathway. BAFFR expression correlates with BCR surface expression and tonic signaling, and BAFFR signaling contributes to the differentiation of immature into transitional B cells. The scheme is based on data from Rowland et al. 2010a,b.

found that tonic BCR signaling that promotes cell differentiation requires phosphorylation of the Erk MAP kinase (Fig. 4), and that activation of the Ras-Mek-Erk signaling pathway in immature $\mathrm{B}$ cells mimics tonic BCR signaling promoting their differentiation into transitional $\mathrm{B}$ cells (Rowland et al. 2010a). Moreover, enforcing the survival of immature B cells (e.g., with a Bcl-2 transgene) is not sufficient to promote their differentiation (Rowland et al. 2010a), indicating that basal BCR signals are translated onto a cell differentiation program that is independent of cell survival. These findings support those from other studies in which reduced Erk phosphorylation correlated with arrested development of, and sustained Ig gene rearrangement in, CD19-deficient immature B cells (Diamant et al. 2005). Thus, this active signaling pathway promotes positive selection of nonautoreactive immature B cells into the naive B-cell repertoire. In an analogous fashion positive selection of thymocytes and the differentiation of erythrocytes are also dependent on the activation of the Ras-Erk pathway (Alberola-Ila et al. 1996; Werlen et al. 2000; Fischer et al. 2005; McNeil et al. 2005; Schilling et al. 2009), suggesting that this molecular pathway is generally used for the generation of mature hematopoietic cells from their lineage precursors.

Interruption of tonic BCR signaling in immature B cells causes a developmental regression characterized by the reexpression of genes associated with pro-B and pre-B-cell stages of development and the reactivation of $V(D) J$ recombination (Tze et al. 2005; Verkoczy et al. 2007; Schram et al. 2008). Thus, tonic BCR signaling is important for the cessation of both Rag expression and $V(D) J$ recombination and, consequently, promotes allelic exclusion and ensures that each naïve $B$ cell is monospecific. The signaling cascade downstream from tonic BCR signaling appears to be qualitatively different, at least in part, from that induced by selfantigen. Support for this is evidenced by the finding that some immature B cells expressing both an autoreactive and nonautoreactive BCR do not undergo tolerance but instead are allowed to differentiate into mature B cells ( $\mathrm{Li}$ et al. 2002; Liu et al. 2005; Huang et al. 2006). This indicates that tonic BCR signaling, under 
certain circumstances, can override self-antigenmediated BCR signaling. Anergic B-cells may fall into this category, which is cells that experience levels of tonic BCR signals that are sufficient for inhibiting further Ig gene recombination and promote additional differentiation into the transitional B-cell stage despite some level of self-antigen-mediated BCR signaling. Immature B cells that react with self-antigen internalize their engaged BCRs (Pelanda et al. 1997). Thus, these cells experience both antigen-mediated BCR signaling and a lack of tonic BCR signaling. Given that the absence of tonic BCR signaling is sufficient to cause Ig gene recombination (Tze et al. 2005; Verkoczy et al. 2007; Schram et al. 2008), it has been speculated that receptor editing is activated not by antigenmediated BCR signaling but rather by the absence of tonic BCR signaling (Schram et al. 2008).

Based on these findings, we propose that newly generated immature B cells in a wild-type repertoire undergo a dynamic process of selection during which each cell experiences some level of antigen-mediated and tonic BCR signals. The balance between these signals leads to cell differentiation or retention and tolerance. Factors that influence these signals may include avidity for self-antigen, level of surface, and unengaged BCR expression, and possibly certain bone marrow microenvironments.

\section{CYTOKINES AND THE CENTRAL SELECTION NICHE}

Whether defined niches exist in the bone marrow in which newly generated immature B cells test their BCR and undergo B-cell negative and positive selection similar to developing T cells, is not clear. It has only recently been shown that bone marrow stromal cells exist that uniquely secrete CXCL12, IL-7, or galectin-1, and that developing early B lineage cells interact serially with each of these cell types (Tokoyoda et al. 2004; Mourcin et al. 2011). Thus, it is reasonable to consider the existence of additional stromal cells specialized at presenting self-antigens to immature B cells. These stromal cells may also provide specific cytokines and chemoattractants that signal through receptors on im- mature B cells, synergizing with antigen-mediated and tonic BCR signaling and directing developing B cells toward the proper selection pathway.

BAFF, known to promote peripheral B-cell survival (Mackay et al. 2003), may be an example of such a cytokine that contributes to immature B-cell selection. Work from our laboratory has recently shown that nonautoreactive immature B cells express the receptor for BAFF, BAFFR, at levels that correlate with BCR expression and tonic BCR signaling (Fig. 4) (Rowland et al. 2010b). Further, treatment of nonautoreactive immature $\mathrm{B}$ cells with BAFF promotes their differentiation into transitional B cells (Fig. 5) (Rowland et al. 2010b). In contrast, autoreactive immature $\mathrm{B}$ cells express minimal levels of BAFFR (correlating with an absence or minimal tonic BCR signaling) and are unable to respond to BAFF (Rowland et al. 2010b).

On expression of an autoreactive antigen receptor immature $\mathrm{B}$ cells have been shown to survive for at least 2-3 d, during which time tolerance is implemented (Hartley et al. 1993; Melamed and Nemazee 1997; Casellas et al. 2001; Hippen et al. 2005). This period would ensure that autoreactive immature B cells have sufficient time to make several attempts at receptor editing. However, it remains to be established which signals sustain the survival of autoreactive immature B cells during receptor editing. Given that IL-7 is a prosurvival cytokine important for earlier B-cell developmental stages, we asked whether this cytokine may also contribute to autoreactive immature B-cell survival. Findings from these preliminary experiments suggest that IL-7 acts on autoreactive, but not nonautoreactive, immature B cells to extend cell survival in vitro (K. Tuttle, R. Torres, and R. Pelanda, unpubl.). Thus, this cytokine may serve to promote receptor editing over clonal deletion during central B-cell tolerance (Fig. 5).

Recent investigation of the bone marrow environment has determined that immature B cells partition between parenchyma and sinusoids in response to lipids recognized by the cannabinoid receptor 2 (Pereira et al. 2009) and sphingosine 1-phosphate receptor 3 (Donovan et al. 2010). In recent studies we found 

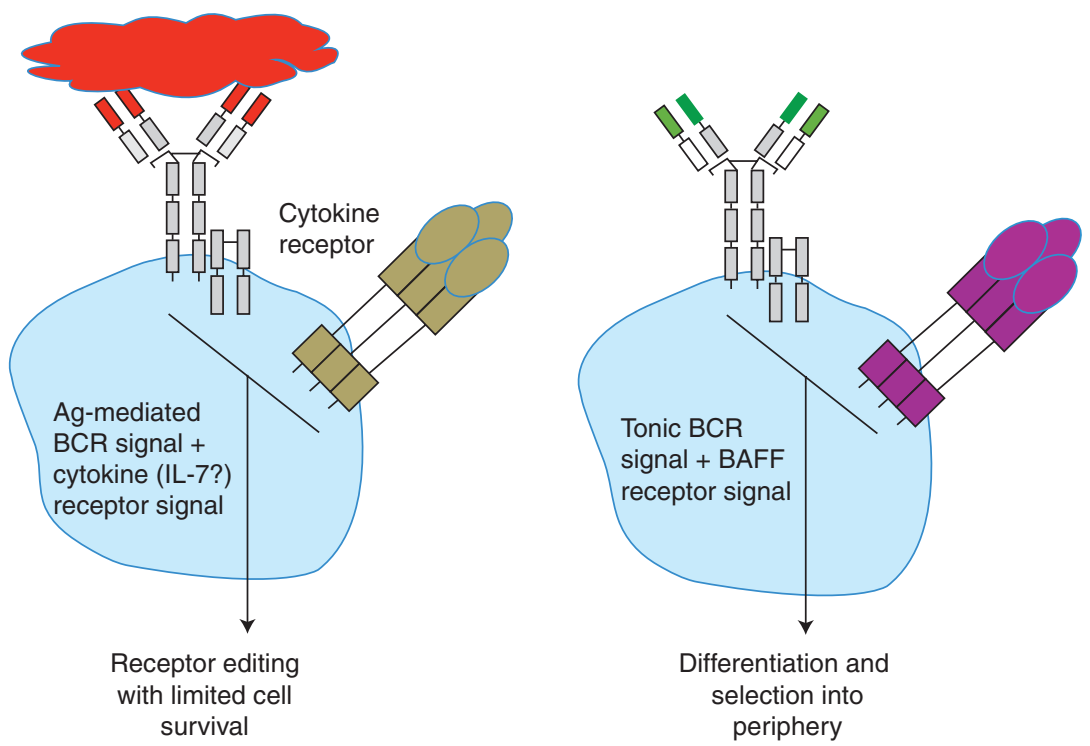

Figure 5. Autoreactive and nonautoreactive immature B cells undergo different fates during bone marrow selection. An autoreactive immature B-cell (on the left) experiences antigen-mediated BCR signaling in addition to the absence of tonic BCR signaling, and these events promote ongoing Ig gene rearrangements (receptor editing). Cytokines, such as IL-7, may be able to sustain limited cell survival during the editing process. A nonautoreactive immature B cell (on the right) experiences tonic BCR signaling in addition to BAFFR signaling, and these events promote further cell differentiation and selection into the peripheral B-cell compartment.

that only nonautoreactive immature B cells, including those generated after receptor editing, localize in the sinusoids (Donovan et al. 2010). In contrast, autoreactive immature B cells are restricted to the parenchyma of the bone marrow (Donovan et al. 2010), suggesting that sinusoid localization before exiting the bone marrow may be important for proper B-cell differentiation. Whether BAFF and/or other promaturation cytokines are differentially expressed in the sinusoids of the bone marrow tissue is not known, but we predict that more detailed analysis of this particular environment will reveal defined niches in which developing B lymphocytes compartmentalize for proper differentiation and selection.

\section{CONCLUDING REMARKS}

The studies of central B-cell tolerance performed in the last 30 years in mice have given us an understanding of what are the general forces that shape the murine naïve B-cell reper- toire. Future challenges will be to extend our current knowledge to the human immune system to determine whether human autoreactive immature B cells are also capable of undergoing receptor editing, and whether clonal deletion is a default mechanism or rather a primary tolerance process in human central B-cell tolerance. Another challenge will be to increase our knowledge of the bone marrow microenvironment to establish whether a specific niche exists for selfantigen presentation to newly generated B cells, and for the processes of negative and positive selection. In particular, we will need to define the cytokines and chemoattractants that influence immature B-cell selection and their distribution in the marrow environment. Another major challenge will be to determine what factors regulate tonic BCR signaling in immature $B$ cells, and particularly what defines the signaling threshold that separates negative and positive selection. Finally, these findings will have to be applied to our understanding of diseases, to determine whether individuals prone to B-cell- 
mediated autoimmunity harbor immature autoreactive B cells that have abnormal BCR tuning and/or aberrant bone marrow microenvironments.

\section{ACKNOWLEDGMENTS}

We thank present and past members of the Torres and Pelanda laboratories who have contributed to the work and discussions presented here. Work in the authors' laboratory was and/or is supported by National Institutes of Health grants AI022295, AI052310, AI052157, AI078468, and the Arthritis Foundation.

\section{REFERENCES}

Ait-Azzouzene D, Verkoczy L, Peters J, Gavin A, Skog P, Vela JL, Nemazee D. 2005. An immunoglobulin C к-reactive single chain antibody fusion protein induces tolerance through receptor editing in a normal polyclonal immune system. J Exp Med 201: 817-828.

Ait-Azzouzene D, Verkoczy L, Duong B, Skog P, Gavin AL, Nemazee D. 2006. Split tolerance in peripheral B cell subsets in mice expressing a low level of Igк-reactive ligand. J Immunol 176: 939-948.

Alberola-Ila J, Hogquist KA, Swan KA, Bevan MJ, Perlmutter RM. 1996. Positive and negative selection invoke distinct signaling pathways. J Exp Med 184: 9-18.

Allman D, Lindsley RC, DeMuth W, Rudd K, Shinton SA Hardy RR. 2001. Resolution of three nonproliferative immature splenic B cell subsets reveals multiple selection points during peripheral B cell maturation. J Immunol 167: 6834-6840.

Arakawa H, Shimizu T, Takeda S. 1996. Re-evaluation of the probabilities for productive arrangements on the $\kappa$ and $\lambda$ loci. Int Immunol 8: 91-99.

Bannish G, Fuentes-Panana EM, Cambier JC, Pear WS, Monroe JG. 2001. Ligand-independent signaling functions for the B lymphocyte antigen receptor and their role in positive selection during B lymphopoiesis. J Exp Med 194: 1583-1596.

Barreto V, Cumano A. 2000. Frequency and characterization of phenotypic Ig heavy chain allelically included IgM-expressing B cells in mice. J Immunol 164: 893-899.

Benschop RJ, Aviszus K, Zhang X, Manser T, Cambier JC, Wysocki LJ. 2001. Activation and anergy in bone marrow B cells of a novel immunoglobulin transgenic mouse that is both hapten specific and autoreactive. Immunity 14: 33-43.

Brekke KM, Garrard WT. 2004. Assembly and analysis of the mouse immunoglobulin $\kappa$ gene sequence. Immunogenetics 56: 490-505.

Burnet FM. 1959. Clonal selection theory of acquired immunity. Cambridge University Press, London, and Vanderbilt University Press, Nashville.
Carson S, Wu GE. 1989. A linkage map of the mouse immunoglobulin $\lambda$ light chain locus. Immunogenetics 29: 173-179.

Casellas R, Shih TA, Kleinewietfeld M, Rakonjac J, Nemazee D, Rajewsky K, Nussenzweig MC. 2001. Contribution of receptor editing to the antibody repertoire. Science 291: $1541-1544$.

Casellas R, Zhang Q, Zheng NY, Mathias MD, Smith K, Wilson PC. 2007. Igא allelic inclusion is a consequence of receptor editing. J Exp Med 204: 153-160.

Cerny A, Heusser C, Sutter S, Huegin AW, Bazin H, Hengartner H, Zinkernagel RM. 1986. Generation of agammaglobulinaemic mice by prenatal and postnatal exposure to polyclonal or monoclonal anti-IgM antibodies. Scand J Immunol 24: 437-445.

Chen C, Nagy Z, Prak EL, Weigert M. 1995a. Immunoglobulin heavy chain gene replacement: A mechanism of receptor editing. Immunity 3: 747-755.

Chen C, Nagy Z, Radic MZ, Hardy RR, Huszar D, Camper SA, Weigert M. 1995b. The site and stage of anti-DNA B-cell deletion. Nature 373: 252-255.

Diamant E, Keren Z, Melamed D. 2005. CD19 regulates positive selection and maturation in B lymphopoiesis: Lack of CD19 imposes developmental arrest of immature B cells and consequential stimulation of receptor editing. Blood 105: 3247-3254.

Donovan EE, Pelanda R, Torres RM. 2010. S1P3 confers differential S1P-induced migration by autoreactive and non-autoreactive immature B cells and is required for normal B-cell development. Eur J Immunol 40: 688-698.

Doyle CM, Han J, Weigert MG, Prak ET. 2006. Consequences of receptor editing at the $\lambda$ locus: Multireactivity and light chain secretion. Proc Natl Acad Sci 103: 1126411269.

Fanning L, Bertrand FE, Steinberg C, Wu GE. 1998. Molecular mechanisms involved in receptor editing at the Ig heavy chain locus. Int Immunol 10: 241-246.

Finkelman FD, Mond JJ, Metcalf ES. 1983. Effects of neonatal anti-delta antibody treatment on the murine immune system. I. Suppression of development of surface $\operatorname{IgD}^{+} \mathrm{B}$ cells and expansion of a surface $\operatorname{IgM}^{+} \operatorname{IgD}^{-}$B lymphocyte population. J Immunol 131: 593-600.

Fischer AM, Katayama CD, Pages G, Pouyssegur J, Hedrick SM. 2005. The role of erk 1 and erk 2 in multiple stages of T cell development. Immunity 23: 431-443.

Gause A, Yoshida N, Kappen C, Rajewsky K. 1987. In vivo generation and function of $\mathrm{B}$ cells in the presence of a monoclonal anti-IgM antibody: Implications for B cell tolerance. Eur J Immunol 17: 981-990.

Gay D, Saunders T, Camper S, Weigert M. 1993. Receptor editing: An approach by autoreactive B cells to escape tolerance. J Exp Med 177: 999-1008.

Giachino C, Padovan E, Lanzavecchia A. 1995. $\kappa^{+} \lambda^{+}$dual receptor $\mathrm{B}$ cells are present in the human peripheral repertoire. J Exp Med 181: 1245-1250.

Goodnow CC, Crosbie J, Adelstein S, Lavoie TB, Smith-Gill SJ, Brink RA, Pritchard-Briscoe $\mathrm{H}$, Wotherspoon JS, Loblay RH, Raphael K, et al. 1988. Altered immunoglobulin expression and functional silencing of self-reactive B lymphocytes in transgenic mice. Nature 334: 676-682. 
Gordon J, Murgita RA, Tomasi TB Jr. 1975. The immune response of mice treated with anti- $\mu$ antibodies: The effect on antibody-forming cells, their precursors and helper cells assayed in vitro. J Immunol 114: 1808-1812.

Grandien A, Fucs R, Nobrega A, Andersson J, Coutinho A. 1994. Negative selection of multireactive B cell clones in normal adult mice. Eur J Immunol 24: 1345-1352.

Halverson R, Torres RM, Pelanda R. 2004. Receptor editing is the main mechanism of $\mathrm{B}$ cell tolerance toward membrane antigens. Nat Immunol 5: 645-650.

Hardy RR, Carmack CE, Shinton SA, Kemp JD, Hayakawa K. 1991. Resolution and characterization of pro-B and pre-pro-B cell stages in normal mouse bone marrow. $J$ Exp Med 173: 1213-1225.

Hartley SB, Crosbie J, Brink R, Kantor AB, Basten A, Goodnow CC. 1991. Elimination from peripheral lymphoid tissues of self-reactive B lymphocytes recognizing membrane-bound antigens. Nature 353: 765-769.

Hartley SB, Cooke MP, Fulcher DA, Harris AW, Cory S, Basten A, Goodnow CC. 1993. Elimination of self-reactive B lymphocytes proceeds in two stages: Arrested development and cell death. Cell 72: 325-335.

Hayakawa K, Asano M, Shinton SA, Gui M, Wen LJ, Dashoff J, Hardy RR. 2003. Positive selection of anti-thy-1 autoreactive B-1 cells and natural serum autoantibody production independent from bone marrow B cell development. J Exp Med 197: 87-99.

Heltemes LM, Manser T. 2002. Level of B cell antigen receptor surface expression influences both positive and negative selection of B cells during primary development. $J$ Immunol 169: 1283-1292.

Hewitt SL, Farmer D, Marszalek K, Cadera E, Liang HE, Xu Y, Schlissel MS, Skok JA. 2008. Association between the Igk and Igh immunoglobulin loci mediated by the $3^{\prime}$ Igk enhancer induces 'decontraction' of the Igh locus in pre-B cells. Nat Immunol 9: 396-404.

Hippen KL, Schram BR, Tze LE, Pape KA, Jenkins MK, Behrens TW. 2005. In vivo assessment of the relative contributions of deletion, anergy, and editing to B cell selftolerance. J Immunol 175: 909-916.

Huang H, Kearney JF, Grusby MJ, Benoist C, Mathis D. 2006. Induction of tolerance in arthritogenic B cells with receptors of differing affinity for self-antigen. Proc Natl Acad Sci 103: 3734-3739.

Inlay MA, Lin T, Gao HH, Xu Y. 2006. Critical roles of the immunoglobulin intronic enhancers in maintaining the sequential rearrangement of IgH and Igk loci. J Exp Med 203: 1721-1732.

Kohler F, Hug E, Eschbach C, Meixlsperger S, Hobeika E, Kofer J, Wardemann H, Jumaa H. 2008. Autoreactive B cell receptors mimic autonomous pre-B cell receptor signaling and induce proliferation of early B cells. Immunity 29: 912-921.

Koralov SB, Novobrantseva TI, Konigsmann J, Ehlich A, Rajewsky K. 2006. Antibody repertoires generated by VH replacement and direct $\mathrm{VH}$ to $\mathrm{JH}$ joining. Immunity 25: $43-53$.

Lawton AR III, Asofsky R, Hylton MB, Cooper MD. 1972. Suppression of immunoglobulin class synthesis in mice. I. Effects of treatment with antibody to $\mu$-chain. $J$ Exp Med 135: 277-297.
Li Y, Li H, Weigert M. 2002. Autoreactive B cells in the marginal zone that express dual receptors. J Exp Med 195: $181-188$.

Liu S, Velez MG, Humann J, Rowland S, Conrad FJ, Halverson R, Torres RM, Pelanda R. 2005. Receptor editing can lead to allelic inclusion and development of $\mathrm{B}$ cells that retain antibodies reacting with high avidity autoantigens. J Immunol 175: 5067-5076.

Liu Y, Li L, Mohan C. 2008. The role of rearrangement at the second Ig heavy chain locus in maintaining B cell tolerance to DNA. J Immunol 180: 7721-7727.

Loder F, Mutschler B, Ray RJ, Paige CJ, Sideras P, Torres R, Lamers MC, Carsetti R. 1999. B cell development in the spleen takes place in discrete steps and is determined by the quality of B cell receptor-derived signals. J Exp Med 190: $75-89$.

Mackay F, Schneider P, Rennert P, Browning J. 2003. BAFF and APRIL: A tutorial on B cell survival. Annu Rev Immunol 21: 231-264.

Manning DD, Jutila JW. 1972. Immunosuppression of mice injected with heterologous anti-immunoglobulin heavy chain antisera. J Exp Med 135: 1316-1333.

Martinez-Jean C, Folch G, Lefranc MP. 2001. Nomenclature and overview of the mouse (Mus musculus and Mus sp.) immunoglobulin к (IGK) genes. Exp Clin Immunogenet 18: $255-279$.

McNeil LK, Starr TK, Hogquist KA. 2005. A requirement for sustained ERK signaling during thymocyte positive selection in vivo. Proc Natl Acad Sci 102: 13574-13579.

Melamed D, Nemazee D. 1997. Self-antigen does not accelerate immature B cell apoptosis, but stimulates receptor editing as a consequence of developmental arrest. Proc Natl Acad Sci 94: 9267-9272.

Moore MW, Durdik J, Persiani DM, Selsing E. 1985. Deletions of $\kappa$ chain constant region genes in mouse $\lambda$ chainproducing $B$ cells involve intrachromosomal DNA recombinations similar to V-J joining. Proc Natl Acad Sci 82: 6211-6215.

Mouquet H, Scheid JF, Zoller MJ, Krogsgaard M, Ott RG, Shukair S, Artyomov MN, Pietzsch J, Connors M, Pereyra F, et al. 2010. Polyreactivity increases the apparent affinity of anti-HIV antibodies by heteroligation. Nature 467: 591-595.

Mourcin F, Breton C, Tellier J, Narang P, Chasson L, Jorquera A, Coles M, Schiff C, Mancini SJ. 2011. Galectin-1 expressing stromal cells constitute a specific niche for preBII cell development in mouse bone marrow. Blood 117: 6552-6561.

Muller B, Reth M. 1988. Ordered activation of the Ig $\lambda$ locus in Abelson B cell lines. J Exp Med 168: 2131-2137.

Nemazee DA, Burki K. 1989. Clonal deletion of B lymphocytes in a transgenic mouse bearing anti-MHC class I antibody genes. Nature 337: 562-566.

Pelanda R, Schaal S, Torres RM, Rajewsky K. 1996. A prematurely expressed Igк transgene, but not VкЈк gene segment targeted into the Igк locus, can rescue B cell development in $\lambda 5$-deficient mice. Immunity 5: 229239.

Pelanda R, Schwers S, Sonoda E, Torres RM, Nemazee D, Rajewsky K. 1997. Receptor editing in a transgenic mouse 
model: Site, efficiency, and role in B cell tolerance and antibody diversification. Immunity 7: 765-775.

Pereira JP, An J, Xu Y, Huang Y, Cyster JG. 2009. Cannabinoid receptor 2 mediates the retention of immature B cells in bone marrow sinusoids. Nat Immunol 10: 403411.

Persiani DM, Durdik J, Selsing E. 1987. Active $\lambda$ and $\kappa$ antibody gene rearrangement in Abelson murine leukemia virus-transformed pre-B cell lines. J Exp Med 165: 1655-1674.

Radic MZ, Erikson J, Litwin S, Weigert M. 1993. B lymphocytes may escape tolerance by revising their antigen receptors. J Exp Med 177: 1165-1173.

Reichman-Fried M, Hardy RR, Bosma MJ. 1990. Development of B-lineage cells in the bone marrow of scid/scid mice following the introduction of functionally rearranged immunoglobulin transgenes. Proc Natl Acad Sci 87: $2730-2734$.

Rezanka LJ, Kenny JJ, Longo DL. 2005. Dual isotype expressing $B$ cells $\left(\kappa^{+} / \lambda^{+}\right)$arise during the ontogeny of $B$ cells in the bone marrow of normal nontransgenic mice. Cell Immunol 238: 38-48.

Rowland SL, DePersis CL, Torres RM, Pelanda R. 2010a. Ras activation of Erk restores impaired tonic BCR signaling and rescues immature B cell differentiation. J Exp Med 207: 607-621.

Rowland SL, Leahy KF, Halverson R, Torres RM, Pelanda R. 2010b. BAFF receptor signaling aids the differentiation of immature B cells into transitional B cells following tonic BCR signaling. J Immunol 185: 4570-4581.

Sakano H, Kurosawa Y, Weigert M, Tonegawa S. 1981. Identification and nucleotide sequence of a diversity DNA segment (D) of immunoglobulin heavy-chain genes. $\mathrm{Na}$ ture 290: $562-565$.

Samuels J, Ng YS, Coupillaud C, Paget D, Meffre E. 2005. Impaired early B cell tolerance in patients with rheumatoid arthritis. J Exp Med 201: 1659-1667.

Schilling M, Maiwald T, Hengl S, Winter D, Kreutz C, Kolch W, Lehmann WD, Timmer J, Klingmuller U. 2009. Theoretical and experimental analysis links isoform-specific ERK signalling to cell fate decisions. Mol Syst Biol 5: 334.

Schram BR, Tze LE, Ramsey LB, Liu J, Najera L, Vegoe AL, Hardy RR, Hippen KL, Farrar MA, Behrens TW. 2008. $\mathrm{B}$ cell receptor basal signaling regulates antigen-induced Ig light chain rearrangements. J Immunol 180: 47284741.

Shimizu T, Iwasato T, Yamagishi H. 1991. Deletions of immunoglobulin CK region characterized by the circular excision products in mouse splenocytes. J Exp Med 173: 1065-1072.

Spanopoulou E, Roman CA, Corcoran LM, Schlissel MS, Silver DP, Nemazee D, Nussenzweig MC, Shinton SA, Hardy RR, Baltimore D. 1994. Functional immunoglobulin transgenes guide ordered B-cell differentiation in Rag-1-deficient mice. Genes Dev 8: 1030-1042.

Su TT, Rawlings DJ. 2002. Transitional B lymphocyte subsets operate as distinct checkpoints in murine splenic B cell development. J Immunol 168: 2101-2110.

Takemori T, Rajewsky K. 1984. Specificity, duration and mechanism of idiotype suppression induced by neonatal injection of monoclonal anti-idiotope antibodies into mice. Eur J Immunol 14: 656-667.

Tarlinton D, Light A, Metcalf D, Harvey RP, Robb L. 2003. Architectural defects in the spleens of Nkx2-3-deficient mice are intrinsic and associated with defects in both $\mathrm{B}$ cell maturation and $\mathrm{T}$ cell-dependent immune responses. J Immunol 170: 4002-4010.

Tiegs SL, Russell DM, Nemazee D. 1993. Receptor editing in self-reactive bone marrow B cells. J Exp Med 177: 10091020.

Tokoyoda K, Egawa T, Sugiyama T, Choi BI, Nagasawa T. 2004. Cellular niches controlling B lymphocyte behavior within bone marrow during development. Immunity 20: 707-718.

Tokuhisa T, Gadus FT, Herzenberg LA. 1981. Monoclonal antibody to an IgD allotype induces a new type of allotype suppression in the mouse. J Exp Med 154: 921-934.

Tze LE, Schram BR, Lam KP, Hogquist KA, Hippen KL, Liu J, Shinton SA, Otipoby KL, Rodine PR, Vegoe AL, et al. 2005. Basal immunoglobulin signaling actively maintains developmental stage in immature B cells. PLoS Biol 3: e82.

van der Burg M, Tumkaya T, Boerma M, de Bruin-Versteeg S, Langerak AW, van Dongen JJ. 2001. Ordered recombination of immunoglobulin light chain genes occurs at the IGK locus but seems less strict at the IGL locus. Blood 97: 1001-1008.

Velez MG, Kane M, Liu S, Gauld SB, Cambier JC, Torres RM, Pelanda R. 2007. Ig allotypic inclusion does not prevent B cell development or response. J Immunol 179: 10491057.

Verkoczy L, Duong B, Skog P, Ait-Azzouzene D, Puri K, Vela JL, Nemazee D. 2007. Basal B cell receptor-directed phosphatidylinositol 3-kinase signaling turns off RAGs and promotes B cell-positive selection. J Immunol 178: 6332-6341.

Wang LD, Lopes J, Cooper AB, Dang-Lawson M, Matsuuchi L, Clark MR. 2004. Selection of B lymphocytes in the periphery is determined by the functional capacity of the B cell antigen receptor. Proc Natl Acad Sci 101: 1027-1032.

Wardemann H, Yurasov S, Schaefer A, Young JW, Meffre E, Nussenzweig MC. 2003. Predominant autoantibody production by early human B cell precursors. Science 301: 1374-1377.

Wen L, Brill-Dashoff J, Shinton SA, Asano M, Hardy RR, Hayakawa K. 2005. Evidence of marginal-zone B cellpositive selection in spleen. Immunity 23: 297-308.

Werlen G, Hausmann B, Palmer E. 2000. A motif in the $\alpha \beta$ T-cell receptor controls positive selection by modulating ERK activity. Nature 406: 422-426.

Xu H, Li H, Suri-Payer E, Hardy RR, Weigert M. 1998. Regulation of anti-DNA B cells in recombination-activating gene-deficient mice. J Exp Med 188: 1247-1254.

Yamagami T, ten Boekel E, Andersson J, Rolink A, Melchers F. 1999. Frequencies of multiple IgL chain gene rearrangements in single normal or $\mathrm{KL}$ chain-deficient B lineage cells. Immunity 11: 317-327.

Young F, Ardman B, Shinkai Y, Lansford R, Blackwell TK, Mendelsohn M, Rolink A, Melchers F, Alt FW. 1994. 
Influence of immunoglobulin heavy- and light-chain expression on B-cell differentiation. Genes Dev 8: $1043-$ 1057.

Yurasov S, Wardemann H, Hammersen J, Tsuiji M, Meffre E, Pascual V, Nussenzweig MC. 2005. Defective B cell tolerance checkpoints in systemic lupus erythematosus. J Exp Med 201: 703-711.
Zachau HG. 2000. The immunoglobulin $\kappa$ gene families of human and mouse: A cottage industry approach. Biol Chem 381: 951-954.

Zhang Z, Zemlin M, Wang YH, Munfus D, Huye LE, Findley HW, Bridges SL, Roth DB, Burrows PD, Cooper MD. 2003. Contribution of Vh gene replacement to the primary B cell repertoire. Immunity 19: 21-31. 


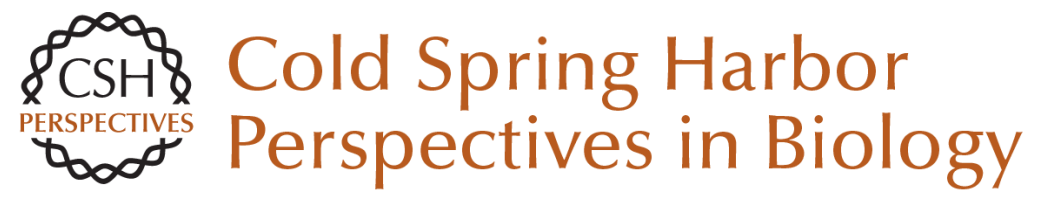

\section{Central B-Cell Tolerance: Where Selection Begins}

Roberta Pelanda and Raul M. Torres

Cold Spring Harb Perspect Biol 2012; doi: 10.1101/cshperspect.a007146 originally published online February 28, 2012

\section{Subject Collection Immune Tolerance}

Regulatory T Cells and Immune Tolerance in the Intestine

Oliver J. Harrison and Fiona M. Powrie

Dendritic Cells: Arbiters of Immunity and

Immunological Tolerance Kanako L. Lewis and Boris Reizis

Current and Future Immunomodulation Strategies to Restore Tolerance in Autoimmune Diseases Jeffrey A. Bluestone and Hélène Bour-Jordan

T-Cell Tolerance: Central and Peripheral Yan Xing and Kristin A. Hogquist

\section{Central B-Cell Tolerance: Where Selection Begins} Roberta Pelanda and Raul M. Torres

The Immunogenetic Architecture of Autoimmune Disease An Goris and Adrian Liston
Regulatory T Cells and Immune Tolerance in the Intestine

Oliver J. Harrison and Fiona M. Powrie

Microbiota and Autoimmunity Alexander V. Chervonsky

Treg Cells, Life History, and Diversity Christophe Benoist and Diane Mathis

Infectious (Non)tolerance--Frustrated

Commensalism Gone Awry? Jesse C. Nussbaum and Richard M. Locksley

Historical Overview of Immunological Tolerance Ronald H. Schwartz

Natural Killer Cell Tolerance: Control by Self or

Self-Control?

Baptiste N. Jaeger and Eric Vivier

For additional articles in this collection, see http://cshperspectives.cshlp.org/cgi/collection/

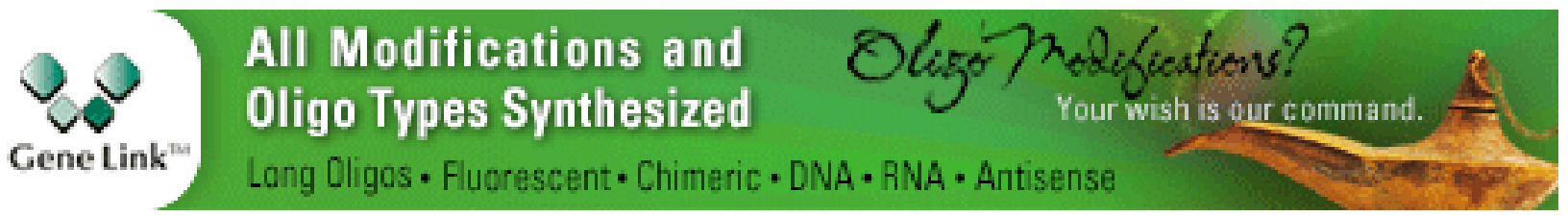

Copyright @ 2012 Cold Spring Harbor Laboratory Press; all rights reserved 